
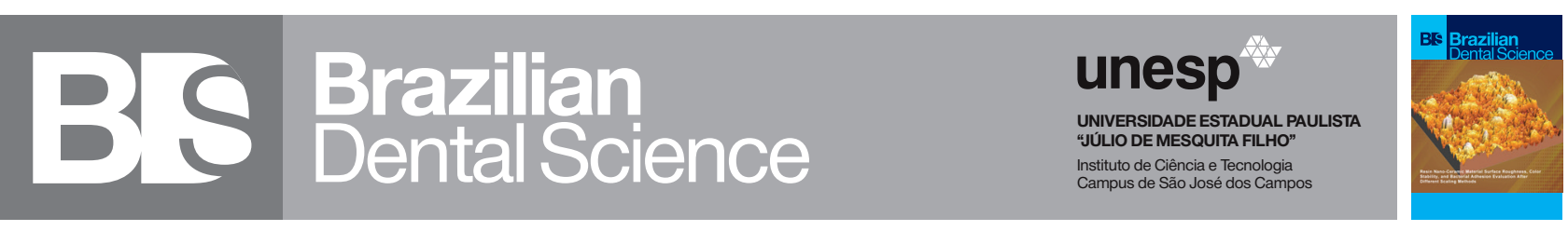

\title{
Fracture Resistance of Primary Molars Restored with Endocrowns Versus Zirconia Crowns (An in Vitro Study)
}

Resistência à fratura de molares decíduos restaurados com endocrowns versus coras de zircônia (um estudo in vitro)

Ayman Abdel Hamid SABBAH ${ }^{1}$, Mostafa Hussein KAMEL ${ }^{2}$

1 - Misr International University, Faculty of Oral and Dental Medicine, Pediatric Dentistry Department, Cairo, Egypt.

2 - Misr International University, Faculty of Oral and Dental Medicine, Fixed Prosthodontics Department, Cairo, Egypt.

\section{ABSTRACT}

Objective: This study aimed to assess the fracture resistance of primary molars restored with endocrowns compared to prefabricated zirconia crowns. Material and Methods: Twelve sound, defect-free primary second molars were selected and divided into two groups: group I included 6 molars restored with zirconia crowns, while group II included 6 teeth restored with endocrowns. For both groups access cavity was prepared for the teeth to open pulp chamber. Fracture resistance of both groups was tested using a universal testing machine. Results: Zirconia crown showed statistically significantly higher mean fracture resistance than Endocrown (P-value $=0.001$, Effect size $=$ 2.72). Conclusion: Pulpotomized primary molars restored with Zirconia crowns showed significantly higher mean fracture resistance compared to primary molars restored with endocrowns, meanwhile both restorations have shown higher mean fracture resistance than the maximum biting force in children.

\section{KEYWORDS}

Composite resins; Endocrown; Fracture strength; Zirconia crowns.

\section{RESUMO}

Objetivo: Este estudo teve como objetivo avaliar a resistência à fratura de molares decíduos restaurados com endocrowns em comparação com coroas de zircônia pré-fabricadas. Material e Métodos: Doze segundos molares decíduos hígidos e livres de defeitos foram selecionados e divididos em dois grupos: o grupo 1 incluiu 6 molares restaurados com coroas de zircônia, enquanto o grupo 11 incluiu 6 dentes restaurados com edocrowns. Para ambos os grupos, foi preparada uma cavidade de acesso à câmara pulpar. A resistência à fratura de ambos os grupos foi testada em uma máquina de ensaio universal. Resultados: A coroa de zircônia apresentou resistência média à fratura estatisticamente significativa maior do que endocrown $(\mathrm{p}=0,001$, Tamanho do efeito $=2,72)$. Conclusão: Molares decíduos pulpotomizados restaurados com coroas de zircônia apresentam resistência média à fratura significativamente maior em comparação aos molares decíduos restaurados com endocrowns, entretanto, ambas as restaurações mostraram maior média à fratura do que a força máxima de mordida em crianças

\section{PALAVRAS-CHAVE}

Resinas compostas; Endocrown; Resistência à fratura; Coroas de zircônia. 


\section{INTRODUCTION}

$\mathrm{E}$ arly Childhood Caries (ECC) is a serious problem that affect preschool children, as it may lead to destruction of the coronal part of the primary teeth partially or completely [1]. Primary molars are highly important in development of occlusion and mastication, so every effort should be done to preserve them. Endodontic treatment usually is the technique of choice, where pulpotomy possess a proper clinical long term serviceability averting pulpectomy step [2], but pulpotomized primary molars are characterized by highly weak remaining tooth structure, which make the tooth more susceptible to fracture under masticatory forces [1]. The restoration of devitalised primary molars should improve their coronal seal, esthetics, functional and mechanical properties $[3,4]$.

When stainless steel crown was introduced to paediatric dentistry in 1947, they remain servicing for decades with a significant durability, but without aesthetic outcome [5]. However, recently there has been an increasing parental demands for aesthetic restorations in the paediatric dental office [6].

Prefabricated zirconia crowns are a new alternate that has become commercially available since 2008, providing excellent aesthetics and mechanical properties similar to metal [5,7], but unfortunately they can't be crimped or contoured and passively fit [5]. Therefore, they demand excessive tooth reduction together with short-term rates of retention documented [7].

Endocrowns are considered successful restorations for endodontically treated molars [8]. They provide better fracture resistance and stress distribution for endodontically treated teeth [810]. These restorations are considered modified onlays gaining retention by bonding with coronal tooth structure and pulp chamber [11-13].

The endocrown restorations possess many advantages as they are prepared supra-gingivally so the restoration is far from the periodontal tissues, resulting in healthier periodontium, preserving more enamel at the periphery, and increasing the surface area for bonding [14,15]. At the beginning, the CEREC system was used to fabricate the endocrown restoration from CAD/ CAM porcelain blocks, but later on composite resin materials were utilized due to their highly stress-absorbing properties [14-16].

In paediatric dentistry, composite endocrowns restoration is taken into account as an alternate to prefabricated zirconia crowns due to the conservation of tooth structure and the high cost of porcelain restorations. However, few studies were done to assess endocrowns in primary dentition. So this study was conducted to evaluate the fracture resistance of primary molars restored with endocrowns compared to prefabricated zirconia crowns.

The null hypothesis of this study was that there is no significant difference in fracture resistance between primary molars restored with Zirconia crowns and those restored with composite endocrowns.

\section{MATERIAL AND METHODS}

\section{Specimen Selection and Preparation:}

Twelve sound, defect-free primary second molars were selected for this study. De-identified teeth were obtained from the tooth bank of Misr International University after being disinfected in $10 \%$ formalin to avoid reduction of fracture resistance [17]. Teeth were divided into two groups according to the type of restoration used: group I included 6 primary molars restored with Zirconia crowns (Nusmile, Huston, Texas, USA), while group II included 6 teeth restored with nano-ceramic composite endocrowns (ceram.x SphereTEC one universal, Dentsply Sirona, USA). Simple randomization was performed using Excel software.

For both groups, access cavity was prepared for the teeth to open pulp chamber, simulating the process of pulpotomy for primary molars (Figure 1). 


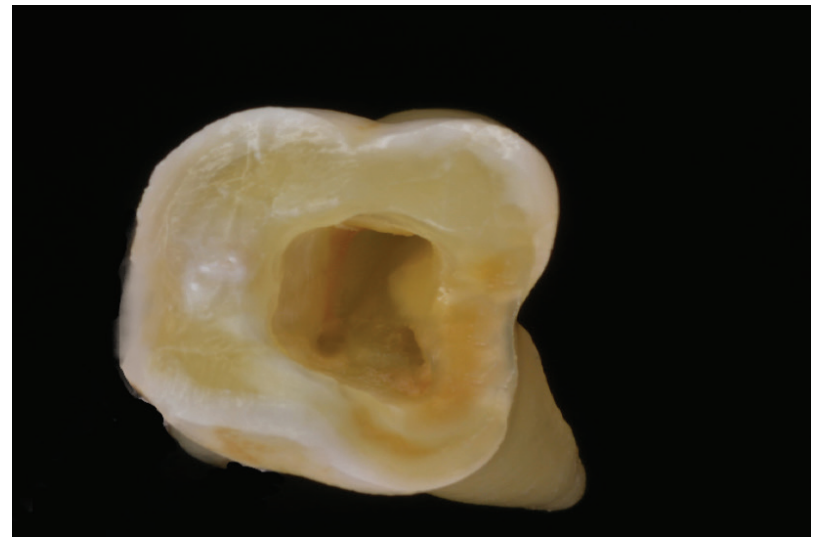

Figure 1 - Pulpotomy and access cavity for primary molar.

\section{Preparation for Zirconia crown:}

In group I specimens, the opened access cavity was filled with composite restoration (ceram.x Sphere TEC one universal, Dentsply Sirona, USA). Teeth were prepared according to the guidelines for preparation of primary molars to receive zirconia crowns with occlusal preparation of $2 \mathrm{~mm}$ to create space for the crown, tapered stone was used to prepare axial walls and open contact to create a feather edge finish line [18] (Figure $2 \mathrm{a}$ and $2 \mathrm{~b}$ ). Zirconia crown size was selected according to the size of the tooth and cemented in place using glass ionomer cement (GC Fuji I, GC America, USA).

\section{Preparation for endocrown:}

As for group II teeth, which were restored with endocrowns (Figure 3a, 3b, 3c and 3d), the cavity design simulated the condition of occlusal mesial cavity, orifices of the canals were sealed with flowable composite (Filtek Supreme, 3M, USA). For calibration of occlusal preparation, tapered stone was used to create depth grooves to obtain the desired amount of occlusal. Preparation of occlusal surface was continued with wheel stone to create $2 \mathrm{~mm}$ occlusal clearance; the occlusal surface was prepared flat to create a buttjoint. The junction between occlusal and mesial cavity was rounded to produce cervical side walk. Divergence of the inner cavity walls was obtained using a tapered stone with rounded end (TR-
12 Dia Bur Mani). Impression was taken for the prepared tooth structure using addition silicone material (Elite HD Zermach, Italy), stone model was poured for fabrication of endocrown to allow for blockage of any undercuts in the pulp chamber cavity. Endocrown was constructed on the stone model using nano-ceramic light cured composite (ceram.x Sphere TEC one universal, Dentsply Sirona, USA), composite was added in increments which were cured using LED light curing unit (Elipar deep cure, 3M, USA) for duration of 40 seconds for each increment. Finished final endocrown restoration was cemented in place using self-adhesive universal dual cured resin cement (rely X Unicem, 3M, USA), which has been cured using LED light curing for 40 seconds and from multiple directions to ensure total curing of the resin cement. For standardization of research procedures all steps were performed by the same operator.

\section{Fracture Resistance Test:}

All samples were subjected to load in a universal testing machine (Instron, Ave Norwood, MA, Usa). Vertical compressive loading of the specimens was applied vertically at a crosshead speed of $0.5 \mathrm{~mm} / \mathrm{min}$ till fracture of the sample. Value of fracture resistance was recorded at the moment of sudden drop of applied force to the sample. The breaking load was recorded in Newton (N).

Table I - Materials used

\begin{tabular}{|c|c|c|}
\hline Materials & Description & Company \\
\hline Nusmile & Zirconia crowns & $\begin{array}{l}\text { Nusmile, Huston, Texas, } \\
\text { USA }\end{array}$ \\
\hline $\begin{array}{c}\text { Ceram.x Sphere TEC one } \\
\text { universal }\end{array}$ & $\begin{array}{l}\text { Nano-ceramic light cured } \\
\text { composite }\end{array}$ & Dentsply Sirona, USA \\
\hline GCFuji I,GC & Glass ionomer cement & America, USA \\
\hline Filtek Supreme, & Flowable composite & 3M, USA \\
\hline Elite HD & Addition silicone material & Zermach, Italy \\
\hline Rely XUnicem & $\begin{array}{l}\text { Self-adhesive universal } \\
\text { dual cured resin cement }\end{array}$ & 3M,USA \\
\hline
\end{tabular}




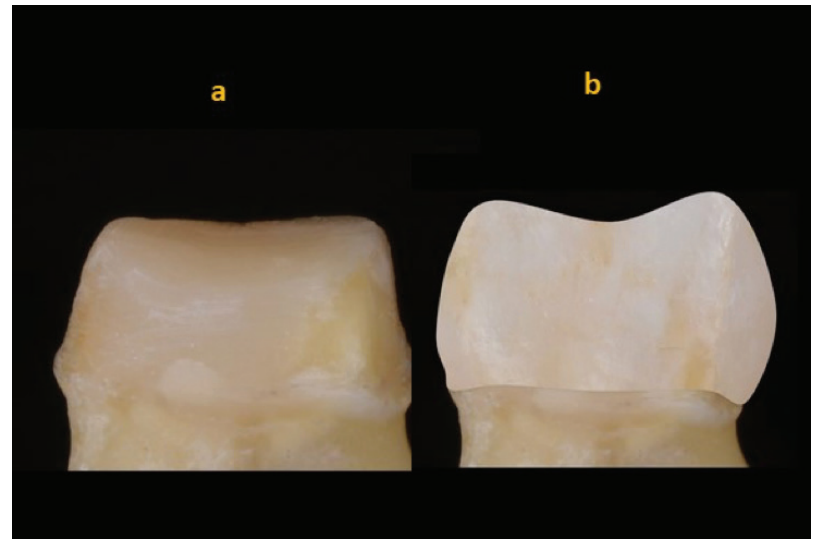

Figure 2 - a) prepared primary molar for Zirconia crown , b) Zirconia crown cemented over primary molar.

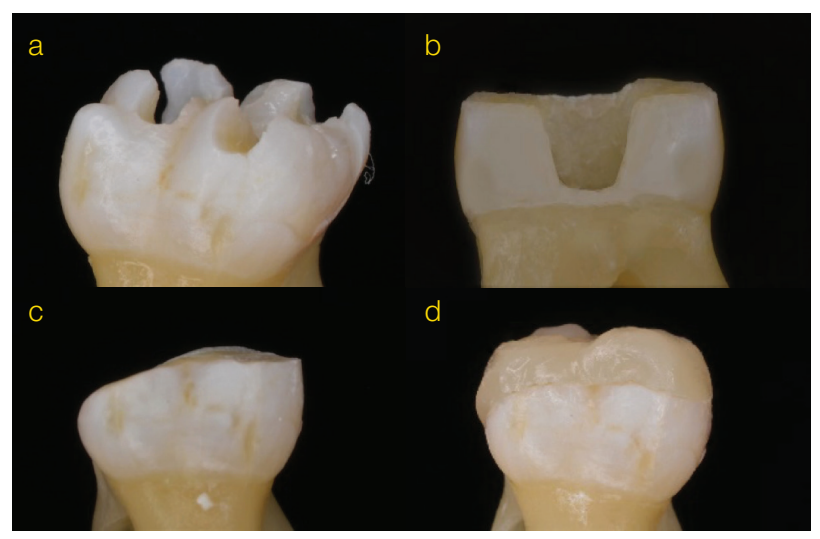

Figure 3 - preparation of primary molars for endocrown . a) depth grooves for occlusal preparation. b) proximal preparation c) preparation for endocrown. d) primary molar restored with composite endocrown.

\section{Sample size calculation}

This power analysis used fracture resistance values obtained from a pilot study using three samples in each group as the primary outcome. The mean \pm SD values were 1075.2 \pm 145.8 and $886 \pm 30.8 \mathrm{~N}$ Zirconia and Endocrown groups, respectively. The effect size (d) was (1.98). Using alpha $(\boldsymbol{\alpha})$ level of $(5 \%)$ and Beta $(\boldsymbol{\beta})$ level of $(20 \%)$ i.e. power $=(80 \%)$; the minimum estimated sample size was (6) samples per group. Sample size calculation was performed using G*Power Version 3.1.9.2.

\section{Statistical Analysis}

Numerical data were explored for normality by checking the distribution of data and using tests of normality (Kolmogorov-Smirnov and Shapiro-Wilk tests). Fracture resistance data showed normal (parametric) distribution. Data were presented as mean and standard deviation (SD) values. Student's t-test was used to compare between the two groups. The significance level was set at $p \leq 0.05$. Statistical analysis was performed with IBM SPSS Statistics for Windows, Version 23.0.1 (IBM Corp, Armonk, NY, USA).

\section{RESULTS}

Prefabricated zirconia crown showed statistically significantly higher mean fracture resistance than endocrown ( $\mathrm{p}$-value $=0.001$, Effect size $=2.72$ ).

Table II - Mean and standard deviation (SD) values and results of Student's t-test for comparison between fracture resistance (Newton) in the two groups

\begin{tabular}{|c|c|c|c|}
\hline \multicolumn{4}{|c|}{ Fracture resistance (N) } \\
\hline & Mean(SD) & p-value & Effect size (d) \\
\hline $\begin{array}{c}\text { Group I } \\
\text { Zirconia crown }\end{array}$ & $1229(192.6)$ & \multirow{2}{*}{$0.001^{*}$} & \multirow{2}{*}{2.72} \\
\hline $\begin{array}{c}\text { Group II } \\
\text { Endocrown }\end{array}$ & $845.4(51.5)$ & & \\
\hline
\end{tabular}

*: Significant at $p \leq 0.05$

\section{DISCUSSION}

Endocrowns have been widely used in the past few years [14] as they can offer a more conservative alternative restoration with accepted esthetics [1,19]. They consisted of two parts: a core and a crown acting as one piece where the macro retention is obtained from the pulp chamber and the micro retention is obtained from the adhesive resin cement $[14,20]$.

Resin endocrown restorations provide more advantages being more economic treatment option as well as reduced preparation time, together with esthetic properties comparable to ceramics [21].

Multiple researches studied the clinical 
performance of endocrown and emphasized in their conclusion its success as restoration for endodontically treated permanent molars $[14,22,23]$. In the current in-vitro study, natural deciduous molars were utilized to nearly simulate the clinical condition in terms of the pulp chamber size, root canals contouring and the crown root ratio [1]. Fracture resistance was measured by mechanical loading method in order to originate stresses at interface between the adhesive and the tooth structure which was the most familiar method used [14,16].

Former research results showed that endocrown used to restore endodontically treated permanent teeth [1] can be applied to deciduous teeth despite the differences between primary and permanent teeth in morphologically and chemically in the form of minimal calcification and wider diameter of the dentinal tubules [24].

In the current study, indirect nano-ceramic composite was preferably used for construction of the indirect endocrown as it has modulus of elasticity matching that of the tooth structure due to the resin content and filler particles which increase the resistance to wear [25].

According to the results of the current study, prefabricated zirconia crown showed statistically significantly higher mean fracture resistance than endocrown. The mean occlusal load that causes fracture of prefabricated zirconia crowns is in consistency with those founded by El Makawi and Khattab 2019 and Vinson et al. 2016 which were $(1420.893 \pm 308.39 \mathrm{~N})$ and $(1214$ (82) N) respectively $[1,26]$, while the results of fracture resistance weren't in agreement with the study done by Altier et al. 2018 which was $2366.50 \mathrm{~b} \pm 420.86$, as this study was performed on permanent teeth [25].

The range of maximum normal force of occlusion may reach $500 \mathrm{~N}$, which may be dependent on the age and the morphology of the face [27]. Nonetheless, in a study done by Braun et al. when the maximal biting force in the first primary molar and the first permanent premolar area where measured, it was found to vary from $78 \mathrm{~N}$ to $106 \mathrm{~N}$ for a 6-year-old and a 10 -year-old child respectively [28]. The findings of a study done to evaluate the biting force of the molar related to occlusion, craniofacial dimensions, and head posture in 7-13 years old children, were $349.2(\mathrm{~N}), 369.3 \mathrm{~N} \& 288.3 \mathrm{~N}$ for Angle Class I, Class II and Class III respectively [29]. In their study, Subramaniam et al. concluded that the children with permanent dentition showed the highest mean occlusal bite force which was 269.7 $\mathrm{N}$ [30].

In the current study, the mean fracture loads used with both materials were higher than the ultimate force of mastication reported. Thus it can be assumed that both materials tested could bear up the ultimate intraoral masticatory forces in the posterior area, enabling both types of restorations to be successful for restoring pulpotomized primary molars. Meanwhile endocrown restorations have the advantage of conservation of tooth structure compared to zirconia crowns.

Limitations of this study include the need for testing fracture resistance under dynamic load to provide more simulation for the oral conditions, and also using different ceramics or hybrid ceramic materials for construction of endocrowns, further studies are required to study the efficacy of endocrowns as restorative option for pulpotomized primary teeth.

The null hypothesis of this study was rejected as mean fracture resistance of primary molars restored with endocrowns was significantly lower than that of the ones restored with zirconia crowns, meanwhile both types of restorations surpassed the maximum occlusal load value in the posterior region. Clinical trials should be done to assist clinicians to assess the clinical efficiency of endocrowns in pulpotomized primary molars. 


\section{CONCLUSION}

Within the limitations of this study, the following could be concluded:

Endocrown can serve as a successful alternative for prefabricated zirconia crown in restoration and protection of pulpotomized primary teeth.

\section{REFERENCES}

1. El Makawi Y, Khattab N.In Vitro comparative analysis of fracture resistance of lithium disilicate endocrown and prefabricated zirconium crown in pulpotomized primary molars. Open Access Maced J Med Sci. 2019;7(23):4094-100. doi:10.3889/oamjms.2019.864.

2. Bossù M, laculli F, Giorgio GD, Salucci A, Polimeni A, Di Carlo S. Different pulp dressing materials for the pulpotomy of primary teeth: a systematic review of the literature. J Clin Med. 2020;9(3): 838. doi: 10.3390/jcm9030838.

3. Rocca G, Krejci I. Crown and post-free adhesive restorations for endodontically treated posterior teeth: from direct composite to endocrowns. Eur J Esthet Dent. 2013;8:156-79.

4. Zhu Z, Dong XY, He S, Pan X, Tang L. Effect of post placement on the restoration of endodontically treated teeth: a systematic review. Int J Prosthodont. 2015;28(5):475-83. doi: 10.11607/ijp.4120.

5. Clark L, Wells MH, Harris EF, Lou J. Comparison of amount of primary tooth reduction required for anterior and posterior zirconia and stainless steel crowns. Pediatr Dent. 2016;38(1):42-6.

6. Zimmerman JA, Feigal RJ, Till MJ, Hodges JS. Parental attitudes on restorative materials as factors influencing current use in pediatric dentistry. Pediatr Dent. 2009;31(1):63-70.

7. Walia T, Salami AA, Bashiri R, Hamoodi OM, Rashid F. A randomised controlled trial of three aesthetic fullcoronal restorations in primary maxillary teeth. Eur J Paediatr Dent. 2014;15:113-8.

8. Chang C-Y, Kuo J-S, Lin Y-S, Chang Y-H. Fracture resistance and failure modes of CEREC endo-crowns and conventional post and core-supported CEREC crowns. J Dent Sci. 2009;4(3):110-7.

9. Gresnigt MM, Özcan M, van den Houten ML, Schipper L, Cune MS. Fracture strength, failure type and Weibull characteristics of lithium disilicate and multiphase resin composite endocrowns under axial and lateral forces. Dent Mater. 2016;32(5):607-14. doi:10.1016/j.dental.2016.01.004.

10. Dejak B, Młotkowski A. 3D-Finite element analysis of molars restored with endocrowns and posts during masticatory simulation. Dent Mater. 2013;29(12):e309-17. doi: 10.1016/j.dental.2013.09.014

11. Bindl A, Mormann WH. Clinical evaluation of adhesively placed Cerec endocrowns after 2 years-preliminary results. J Adhes Dent. 1999;1(3):255-65.

12. Biacchi GR, Mello B, Basting RT. The endocrown: an alternative approach for restoring extensively damaged molars. J Esthet Restor Dent. 2013;25(6):38390. doi: 10.1111/jerd.12065.
13. Rayyan M, Alauti R, Abanmy M, AIReshaid R, Bin HA. Endocrowns versus post-core retained crowns for restoration of compromised mandibular molars: an in vitro study. Int J Comput Dent. 2019;22:39-44.

14. Seddik T, Derelioglu S. Effect of endocrowns on fracture strength and microleakage of endodontically treated primary molar teeth. J Adv Oral Res. 2019;10(2) 113-9. doi: 10.1177/2320206819861223.

15. Rocca GT, Saratti CM, Poncet A, Feilzer AJ, Krejci I. The influence of FRCs reinforcement on marginal adaptation of CAD/CAM composite resin endocrowns after simulated fatigue loading. Odontology. 2016;104:220-32. doi: 10.1007/s10266-015-0202-9.

16. El-Damanhoury HM, Haj-Ali RN, Platt JA. Fracture resistance and microleakage of endocrowns utilizing three CAD-CAM blocks. Oper Dent. 2015:40(2):201-10. doi: 10.2341/13-143-L.

17. Michaud PL, Maleki M, Mello I. Effect of different disinfection/sterilization methods on risk of fracture of teeth used in preclinical dental education. $J$ DentEduc. 2018;82(1):84-87. doi:10.21815/JDE.018.012

18. Al-Haj Ali SN. In vitro comparison of marginal and internal fit between stainless steel crowns and esthetic crowns of primary molars using different luting cements. Dent Res J. 2019;16:366-71. doi: 10.4103/1735-3327.270783.

19. Göhring TN, Peters OA. Restoration of endodontically treated teeth without posts. Am J Dent. 2003 0ct;16(5):313-7.PMID: 14677609.

20. Sedrez-Porto JA, Rosa WL, da Silva AF, Münchow EA, Pereira-Cenci T. Endocrown restorations: a systematic review and meta-analysis. J Dent. 2016;52:8-14. doi:10.1016/j.jdent.2016.07.005.

21. Dietschi D, Duc 0, Krejci I, Sadan A. Biomechanical considerations for the restoration of endodontically treated teeth: a systematic review of the literature, Part II (Evaluation of fatigue behavior, interfaces, and in vivo studies). Quintessence Int. 2008;39(2):117-29.

22. Jeong H, Kim S, Kim J, Choi N. Post-endodontic restoration on erupting permanent first molars using endocrown with a polyglass composite resin: report of two cases. J Korean Acad Pediatr Dent. 2019;46:111-8. doi: 10.5933/ JKAPD.2019.46.1111.

23. Oswal N, Chandak M, Oswal R, Saoji M. Management of endodontically treated teeth with endocrown. J Datta Meghe Inst Med Sci Univ. 2018;13:60. doi:10.4103/jdmimsu.jdmimsu_38_17.

24. Ruschel HC, Ligocki GD, Flaminghi DL, Fossati ACM. Microstructure of mineralized tissues in human primary teeth. J Clin Pediatr Dent. 2015; 35:295-300. doi: 10.17796/jcpd.35.3.918k0t3270v01285.

25. Altier M, Erol F, Yıldırım G, Dalkilic EE. Fracture resistance and failure modes of lithium disilicate or composite endocrowns. Niger J Clin Pract. 2018; 21:821-6. doi: 10.4103/njcp.njcp_175_17.

26. Vinson LA, McCrea MC, Platt JA, Sanders BJ, Jones JE, et al. Fracture resistance of full ceramic primary crowns. J Dent Oral Health Cosmesis. 2016;1:005. doi: 10.24966/DOHC-6783/100005.

27. Al-shibri S, Elguindy J. Fracture resistance of endodontically treated teeth restored with lithium disilicate crowns retained with fiber posts compared to lithium disilicate and cerasmart endocrowns: in vitro study. Dentistry. 2017;7(12):464. doi: 10.4172/2161-1122.1000464.

28. Braun S, Hnat WP, Freudenthaler JW, Marcotte MR, Hönigle K, Johnson BE. A study of maximum bite force during growth and development. Angle Orthod. 1996;66(4):261-4. doi: 10.1043/0003-3219(1996)066«0261:ASOMBF»2.3.C0;2. 
29. Sonnesen L, Bakke M. Molar bite force in relation to occlusion, craniofacial dimensions, and head posture in pre-orthodontic children. Eur J Orthod. 2005;27(1):58-63. doi: 10.1093/ejo/cjh069.
30. Subramaniam P, Girish Babu KL, Ifzah. Evaluation of occlusal forces in different stages of children - An exploratory study. Saudi J Oral Sci 2018;5:116. doi: 10.4103/sjos.SJOralSci 52 17.

\section{Ayman Abdel Hamid Sabbah}

(Corresponding address)

Misr International University, Faculty of Oral and Dental Medicine, Pediatric Dentistry Department, Cairo, Egypt.

Date submitted: 2020 Nov 12

Email: ayman.sabbah@miuegypt.edu.eg

Accept submission: 2021 Jan 28 